Drewitt's work entitled "The Romance of the Apothecaries Garden at Chelsea", which first appeared in 1922 and reached its third edition in 1928 , contains a delightful account of the history of the Garden, including mention of the distinguished men connected with it, such as Sir Hans Sloane, Linnæus and Sir Joseph Banks, its most remarkable trees and other plants, and the present botanical research which is being carried out there. His further interest in botany is shown by a little book on the Latin names of common flowers, published in 1927. His "Life of Edward Jenner, Naturalist and Discoverer of Vaccination", of which the second edition was published in 1933, contains besides the description of the introduction of, and opposition to, vaccination, a lively account of Jenner's early life as a country practitioner and his observations on natural history. In 1931 Drewitt published for the first time "The Note-Book of Edward Jenner in the Possession of the Royal College of Physicians of London, with an Introduction on Jenner's Work as a Naturalist", in which he dealt with Jenner's friendship with John Hunter, Dean Buckland and Sir Humphry Davy. In addition to these works on natural history, Drewitt was the author of "Bombay in the Days of George IV : a Memoir of Chief Justice Sir Edward West", published in 1907.

There is no better example of the truth of Buffon's well-known aphorism than that given by Drewitt, whose polished and kindly nature was reflected in his style. His versatility was shown by his being an accomplished artist and twice exhibiting at the Royal Academy. He had many friends not only in the medical profession but also among laymen, the most notable of whom was Ruskin. He married in 1887 but left no issue. J. D. Rolleston.

We regret to announce the following deaths :

Dr. Arnold Berliner, founder and formerly editor of Die Naturwissenschaften.

Mr. D. B. Mair, formerly assistant Civil Service Commissioner and a distinguished mathematician, on July 21, aged seventy-four.

Sir Allen Mawer, F.B.A., provost of University College, London, an authority on English placenames, on July 22, aged sixty-three.

Prof. John H. Salter, formerly professor of botany in the University College of Wales, Aberystwyth, known also for his work in ornithology, on August 5, aged eighty-one.

Prof. A. L. Selby, emeritus professor of physics in University College, Cardiff, on July 22, aged eightyone.

Prof. R. Willstätter, For. Mem. R.S., formerly professor of chemistry in the University of Munich, on August 3, aged sixty-nine.

Sir Francis Younghusband, K.C.S.I., K.C.I.E., distinguished for his explorations in south-eastern Asia, on July 31, aged seventy-nine.

\section{Astronomy on Postage Stamps}

The dedication of the Mexican National Astrophysical Observatory at Tonanzintla in February last has been marked by the issue by the Mexican Government of a series of six postage stamps devoted entirely to astronomical subjects. The 2c., 5c., 10c., $20 \mathrm{c}$. and $40 \mathrm{c}$. stamps depict respectively the dark nebula in Orion, the solar corona as seen at a total eclipse, the open spiral nebula in Canes Venatici, the edge-on spiral nebula NGC 4594, showing absorption in the central plane, and the ring nebula in Lyra. The 1 peso stamp, departing from the principle of showing spectacular objects such as these, is an experiment which must surely be unique in philately ; it depicts the Hertzsprung-Russell diagram connecting stellar luminosity with spectral type, with the main sequence, the giants, the supergiants and the white dwarfs all duly labelled. The significance of this diagram will certainly escape all but those fairly well grounded in astronomy, but the ordinary user of the stamps of lower denominations cannot fail to be impressed by the grandeur of the objects shown.

\section{Functions of Works Managers}

IN his speech in the House of Commons on July 22 on the work of the Factory Department of the Ministry of Labour and National Service, Mr. Ernest Bevin paid a well-deserved tribute to works managers. The works manager, he asserted, deserves more recognition than he had yet received, and the country owes much to him in this War, as well as to the mines manager, for overcoming problems which no Government department, scientific worker or technician could have foreseen. There is a very close under- standing between the Factory Department and the works managers, who have much in common, being trained, to a very large extent from the same personnel and thus understanding not only each others' problems but each others' approach to the problems. He drew a distinction, which he thinks industry will have to face in the future, between what he called the working directorates who understand the actual operations of the job and he put these working directorates in the same category as works managers. He also emphasized the value of the newly established Factory and Welfare Board as a safeguard against rigid bureaucratic methods. It gives industry and public service a proper place in this branch of adminis tration, and Mr. Bevin thinks that a board of this character will remain a permanent feature to enable us to surmount the changes and difficulties which will arise in our industrial system in the vexed and difficult times ahead. Referring to the Department's policy in encouraging the establishment of personnel managers in the larger factories, he believes that too much is often imposed on the works manager in receiving deputations and like matters and being expected to run the works as well. Much specialization is essential in handling such problems, and the personnel manager as part of the executive is a great asset in large works. Referring to hours of work, Mr. Bevin said that production and mobilization of manpower have now reached a point when matters can be tightened up in respect of hours of work, and the trend of his speech indicated a welcome determination to deal firmly with the question of excessive hours, which are so important a factor in absenteeism and in low production. 